\title{
Prevalence and genotyping of human isolates of Giardia duodenalis from Albania
}

\author{
F. Berrilli ${ }^{\text {a,* }}$, D. Di Cave ${ }^{\text {a }}$, C. D’Orazi ${ }^{\text {b }}$, P. Orecchia ${ }^{a}$, L. Xhelilaj ${ }^{\text {c }}$, D. Bejko ${ }^{\text {c }}$, P. Çaça ${ }^{\text {, }}$, \\ D. Bebeci ${ }^{\text {c }}$, F. Cenko ${ }^{\text {d}}$, D. Donia ${ }^{a}$, M. Divizia ${ }^{\text {a }}$ \\ a Department of Public Health and Cell Biology, Faculty of Medicine, University of Rome "Tor Vergata", Via Montpellier 1, 00133 Rome, Italy \\ b Azienda Ospedaliera Universitaria Policlinico "Tor Vergata", Rome, Italy \\ " University Hospital Centre "Mother Theresa", Paediatric Unit, Tirana, Albania \\ d Albanian Child Survival Project, American Red Cross, Tirana, Albania
}

Received 5 April 2006; received in revised form 20 June 2006; accepted 23 June 2006

Available online 27 July 2006

\begin{abstract}
Microscopical and PCR-based techniques were performed in order to investigate the prevalence of infection and the genotypes of Giardia duodenalis from 125 stool samples collected from children living in the urban and the rural areas of Tirana (Albania) and hospitalized with acute gastroenteritis. 7 out of 125 samples resulted positive for Giardia at the microscopic examination (5.6\%). In 50 selected samples including the 7 samples positive for Giardia by microscopy, 3 and 15 additional positive samples were detected by immunofluorescence and PCR, respectively. Seasonality appeared as an important parameter to be evaluated in order to better understand the prevalence of infection. Sequence analysis revealed both human Assemblage A and B. This result represents the first data on G. duodenalis genotypes in Albania.
\end{abstract}

(C) 2006 Elsevier Ireland Ltd. All rights reserved.

Keywords: Giardia duodenalis; Genotyping; Humans; Albania

Albania is a small country located in the South Eastern Europe between Greece and Serbia and Montenegro and bordering the Adriatic Sea and Ionian Sea. Although Albania's economy is constantly growing, the country is still one of the poorest in Europe, with serious socio-economic concerns which reflect on public health and environmental conditions. The capital Tirana is the most overcrowded city, harbouring approximately one sixth of the entire population of the country. The poor infrastructures of the country have contributed to the increase of environmental pollution and the contamination of water resources. These factors may explain the high frequency of outbreaks of acute gastroenteritis reported [1,2]. Causes of diarrhoea include a wide array of bacteria, viruses and protozoa. Recent studies on microbiological and virological environmental pollution identified the quality of drinking water as a major health problem in the suburbs of the Albanian capital [3-5]. Among protozoan parasites, Giardia duodenalis is recognised

\footnotetext{
* Corresponding author. Tel.: +3906 72596163; fax: +39 0672596040 .
}

E-mail address: berrilli@uniroma2.it (F. Berrilli). as one of the most important non-viral infectious agent causing diarrhoeal illness in humans world-wide [6,7]. Therefore, to obtain information about the presence and the genotypes of Giardia in humans from Albania, a study on hospitalized children from urban and rural areas around Tirana was carried out.

Over a 1-year period, 125 stool samples were obtained from patients with acute gastroenteritis hospitalized in the Paediatric Unit of Tirana Hospital. All subjects were under 9 years of age, coming from the urban area of Tirana and its rural surrounding. To determine the presence of Giardia cysts or trophozoites, faecal samples were concentrated by sedimentation technique and examined as Lugol-stained wet mounts. A sub-sample of 50 isolates, comprising samples assessed positive for Giardia by microscopy, was randomly selected from the starting 125 samples, in order to be representative of rural and urban areas and of both sexes. Of the 50 children, 27 were males and 23 females while 25 originated from urban areas and 25 from rural region. The sub-sample isolates were examined by direct immunofluorescent assay MERIFLUOR Cryptosporidium/ 
Table 1

Positive results, prevalence $(\%)$ and techniques used

\begin{tabular}{lcrc}
\hline & No. positive/no. examined & \multicolumn{1}{c}{$\%$} & \multicolumn{1}{c}{$95 \% \mathrm{CI}$} \\
\hline Microscopy & $7 / 125$ & 5.6 & $1.6-9.6$ \\
Immunofluorescence $^{\mathrm{a}}$ & $10 / 50$ & 20.0 & $8.9-31.1$ \\
PCR $^{\mathrm{a}}$ & $22 / 50$ & 44.0 & $30.2-57.7$ \\
\hline
\end{tabular}

${ }^{\text {a }}$ Fifty selected samples including the 7 samples positive for Giardia by microscopy.

Giardia Monoclonal Antibody Test (Meridian Diagnostics, Cincinnati, Ohio) and by PCR. Genomic DNA was extracted using QIAamp DNA Stool Mini Kit (Qiagen) for PCR and stored at $-20{ }^{\circ} \mathrm{C}$. Genotyping was carried out using a nested PCR procedure to amplify a 130-bp region from the 16S-rRNA gene using the primers RH11 and RH4 [8] and the primers GiarR and GiarF [9]. Sterile distilled water was included as negative control in each batch of DNA extraction and PCR reactions. Bands were visualised on ethidium bromide stained $1 \%$ agarose gels. PCR products were purified using NucleoSpin ${ }^{\circledR}$ Extract (Macherey-Nagel) purification Kit and sequenced. Multiple alignment of sequences was obtained using Clustal X [10]. Prevalence obtained by microscopy, immunofluorescence and by PCR and the relative 95\% confidence intervals (CIs) were calculated [11]. The resulting data were statistically compared using the $\chi^{2}$-test for independence.

Giardia cysts were found in 7 out of the 125 samples examined by microscopy (5.6\% CI 1.6-9.6). Immunofluorescence and PCR of 50 selected samples, including the 7 samples positive for Giardia by microscopy, not only confirmed all microscopically positive isolates, but also detected 3 and 15 additional positive samples, respectively. All immunofluorescence-positive samples were also positive by PCR (Table 1). The prevalence obtained using nested PCR by sex, season (spring/summer vs. autumn/winter) and locality are reported in Table 2. Eleven of the 22 PCR positive isolates originated from urban areas, the other 11 samples from rural regions. A correlation between seasonality and occurrence of Giardia was found $(P=0.004)$. The prevalence of giardiasis appeared higher in warmest months $(51.0 \%$ CI 34.9-67.1) rather than in coldest (23.0\% CI 0.12-45.9). Sequence analysis revealed 10 isolates corresponding to Assemblage A (20.0\%) and 12 isolates to Assemblage B (24.0\%). No mixed assemblages were detected. The distribution of both assemblages by sex, season and locality is shown in Table 2 and no significant correlation was observed.
In general, the prevalence of infection is higher in young people and appear to vary depending on the geographic origin of the studied population, ranging from $1.2 \%$ to $32.0 \%$ [12]. Prevalence observed by molecular analysis in the current study $(44.0 \%)$ are higher than those observed in previous researches based only on microscopical examinations [13]. However, considering that the fifty samples selected contain all of microscopy positives, the infection rates observed by immunofluorescence and PCR may overestimate the prevalence of Giardia infection. Nevertheless, more sensitive techniques such as PCR may indeed detect Giardia infection with low parasitic load or evidence the parasite when it is undetectable in stool sample $[14,15]$. Values of prevalence observed from rural and urban areas are identical, suggesting a comparable risk of infection in both the environment. Most likely, drinking water and contact with animals could be increasingly recognised as the major vehicles for the transmission of the cysts in Albania. Several studies confirm the large circulation of waterborne enteric pathogens in the country because of the large population movement from rural to urban areas and the absence of any wastewater treatment plant $[16,1]$. Seasonality appears to be as a factor associated to the morbidity. The seasonal patterns with highest infection rates in the summer have also been reported in other studies $[17,18]$. Since it is well known that Giardia cysts are able to survive for prolonged periods in the environment also at low temperature, the higher risk during warmer season could be related to an increase of human outdoor activities.

Concerning molecular investigation, the genetic analysis of Giardia isolates evidenced the presence of both human Assemblages A and B. The greatest zoonotic risk is from Assemblage A Giardia genotype and to a lesser measure from Assemblage B genotype which appears to be predominantly human-specific [18]. Recently it has been reported a likely association between assemblage A and subgenotype A2 infections and an increased odds ratios for diarrhoea whereas higher parasite DNA loads and a higher overall prevalence were observed for assemblage B infections which was statistically related with asymptomatic Giardia infection [19]. Since our results showed no significant correlation in the distribution of both assemblages according to the sex, seasonality and locality of the sample, diverse transmission cycles which include both humans and domestic animals are possibly involved. The understanding of the circulation of

Table 2

Giardia prevalence (\%) by PCR and genotypes by sex, season and locality

\begin{tabular}{|c|c|c|c|c|c|c|}
\hline \multicolumn{2}{|c|}{ Sample (no. positive/no. examined) } & \multirow{3}{*}{$\begin{array}{l}\text { Prevalence }(\%) \\
95 \% \text { CI }\end{array}$} & \multicolumn{4}{|c|}{ Genotype } \\
\hline & & & \multicolumn{2}{|c|}{ Assemblage A } & \multicolumn{2}{|c|}{ Assemblage B } \\
\hline & & & Tot & $\% 95 \% \mathrm{CI}$ & Tot & $\% 95 \% \mathrm{CI}$ \\
\hline \multirow[t]{2}{*}{ Sex } & Male $(13 / 27)$ & $48.0(29.0-66.8)$ & 6 & $22.0(6.4-37.6)$ & 7 & $26.0(9.4-42.5)$ \\
\hline & Female $(9 / 23)$ & $39.0(19.0-58.9)$ & 4 & $17.0(1.6-32.3)$ & 5 & $22.0(5.1-38.9)$ \\
\hline \multirow[t]{2}{*}{ Season } & Spring/summer (19/37) & $51.0(34.9-67.0)$ & 8 & $22.0(8.6-35.3)$ & 11 & $30.0(15.2-44.7)$ \\
\hline & Autumn/winter (3/13) & $23.0(0.12-45.9)$ & 2 & $15.0(-4.4-34.4)$ & 1 & $8.0(-6.7-22.7)$ \\
\hline \multirow[t]{2}{*}{ Locality } & Rural (11/25) & $44.0(24.5-63.4)$ & 6 & $24.0(7.2-40.7)$ & 5 & $20.0(4.3-35.6)$ \\
\hline & Urban $(11 / 25)$ & $44.0(24.5-63.4)$ & 4 & $16.0(1.6-30.3)$ & 7 & $28.0(10.4-45.6)$ \\
\hline
\end{tabular}


Giardia genotypes in Albania results particularly relevant, as a consequence of the social isolation of Albania until the beginning of the 1990s and its role as a starting point for massive migration fluxes toward European and non-European countries. The results obtained may reflect the living conditions, lifestyle and environmental situation of the population. As a result, the level of giardiasis could be decreased significantly by implementing relatively simple strategies, such as better wastewater treatment and hygiene education.

\section{References}

[1] Palombi L, Villa L, Divizia M, Cenko F, Siniari V, Rotigliano G, et al. Tirane, Albania: survey on drinking water quality and facilities. Water Sci Technol 2001;43:81-7.

[2] De Soto H, Gordon P, Gedeshi I, Sinoimeri Z, Nayak R. A qualitative assessment of poverty in 10 areas of Albania. Social Development Unit of World Bank (ECSSD); 30 June 2001.

[3] Angjeli V, Reme B, Leno L, Bukli R, Bushati G. Sanitary survey of the drinking water supply of Kombinati suburb-Tirana, Albania. Schriftenr Ver Wasser Boden Lufthyg 2000;105:187-90.

[4] Divizia M, Gabrieli R, Donia D, Macaluso A, Bosch A, Guix S, et al. Waterborne gastroenteritis outbreak in Albania. Water Sci Technol 2004;50:57-61.

[5] Divizia M, Gabrieli R, Macaluso A, Bagnato B, Palombi L, Buonomo E, et al. Nucleotide correlation between HAV Isolates from human patients and environmental samples. J Med Virol 2005;75:8-12.

[6] Thompson RCA, Reynoldson JA, Lymbery AJ. Giardia - from molecules to disease and beyond. Parasitol Today 1993;9:313-5.

[7] Thompson RCA. Giardiasis as a re-emerging infectious disease and its zoonotic potential. Int J Parasitol 2000;30:1259-67.
[8] Hopkins RM, Meloni BP, Groth DM, Wetherall JD, Reynoldson JA, Thompson RCA. Ribosomal RNA sequencing reveals differences between the genotypes of Giardia isolates recovered from humans and dogs living in the same locality. J Parasitol 1997;83:44-51.

[9] Read C, Walters J, Robertson ID, Thompson RCA. Correlation between genotypes of Giardia duodenalis and diarrhoea. Int $\mathrm{J}$ Parasitol 2002;32:229-31.

[10] Thompson JD, Gibson TJ, Plewniak F, Jeanmougin F, Higgins DG. The ClustalX windows interface: flexible strategies for multiple sequence alignment aided by quality analysis tools. Nucleic Acids Res 1997;24: 4876-82.

[11] Bush AO, Lafferty KD, Lotz JM, Shostak AW. Parasitology meets ecology on its own terms: Margolis et al. revisited. J Parasitol 1997;83:575-83.

[12] Monis PT, Thompson RCA. Cryptosporidium and Giardia-zoonoses: fact or fiction? Infect Genet Evol 2003;3:233-44.

[13] Homan WL, Mank TG. Human giardiasis: genotype linked differences in clinical symptomatology. Int J Parasitol 2001;31:822-6.

[14] Amar CFL, East C, Maclure E, McLauchlin J, Jenkins C, Duncanson P, et al. Blinded application of microscopy, bacteriological culture, immunoassays and PCR to detect gastrointestinal pathogens from faecal samples of patients with community-acquired diarrhoea. Eur J Clin Microbiol Infect Dis 2004;23:529-34.

[15] McGlade TR, Robertson ID, Elliot RCA, Thompson RCA. High prevalence of Giardia detected in cats by PCR. Vet Parasitol 2003;110: 197-205.

[16] Furness BW, Beach MJ, Roberts JM. Giardiasis surveillance - United States, 1992-1997. Mor Mortal Wkly Rep CDC Surveill Summ 2000;49:1-13.

[17] Flanagan PA. Giardia - diagnosis, clinical course and epidemiology. A review. Epidemiol Infect 1992;109:1-22.

[18] Thompson RCA. The zoonotic significance and molecular epidemiology of Giardia and giardiasis. Vet Parasitol 2004;126:15-25.

[19] Haque R, Roy S, Kabir M, Stroup SE, Mondal D, Houpt ER. Giardia assemblage A infection and diarrhea in Bangladesh. J Infect Dis 2005;192: 2171-3. 